\title{
Wintering Water Rails Rallus aquaticus in Aust-Agder county, South Norway
}

\author{
Terje Lislevand \& Jan Helge Kjøstvedt
}

Lislevand, T. \& Kjøstvedt, J.H. Wintering water rails Rallus aquaticus in Aust-Agder county, South Norway. - Ornis Norvegica 28: 118-125.

We report the results from censuses of wintering Water Rails along the coast of Aust-Agder county, South Norway, carried out during seven consecutive seasons by using play-back calls. The species is regularly found during mid-winter in this part of the country, with up to 103 birds found in a single season. However, the number fluctuated considerably between years, and there was a positive correlation between total rail numbers and the average autumn temperature (October - December) each year. Data from one of the years showed that the number of birds declined before early spring, but it is not known whether this reduction was caused by mortality, emigration or other factors. The rails generally responded strongly to play-back, most often by replying with the «pig squealing call». Even so, some birds hardly vocalized at all, and a few were totally silent. Hence, the number of birds recorded in this kind of study must be regarded as minimum counts.

Addresses: Terje Lislevand, Department of Biology, University of Bergen, Allégaten 41, N-5007 Bergen, Norway. E-mail:terje.lislevand@zoo.uib.no.Jan Helge Kjфstvedt, N-4770 Høvåg,Norway.E-mail: jankjostvedt@hotmail. com.

\section{INTRODUCTION}

The Water Rail Rallus aquaticus is widely distributed across the Palearctic, and is found north to about 60 degrees in Europe (Cramp \& Simmons 1980, Hagemeijer \& Blair 1997). The European breeding population is estimated to approximately 110000 pairs (Tucker \& Heath 1994) with a stronghold in the eastern part of the continent. European Water Rails are mostly stationary in the south and west, while migratory or partly migratory elsewhere (Cramp \& Simmons 1980). The species normally hides in dense vegetation, and its presence is most easily revealed by its characteristic calls that can be heard at any time of the year. Wintering Water Rails are sensitive to climatic changes, and decreased air temperatures may lead to emigration from wintering sites (Jenkins et al. 1995) or death (Flegg \& Glue 1973).

Little is known about the general occurrence of Water Rails in Norway. Only a few breeding records are known (Haftorn 1971, Bengtson \& Steel 1994, Kjøstvedt \& Lislevand 2001), and closer investigation of the species' distribution and population size is encouraged (Myklebust 1996). The national breeding population is 
assumed to be 100-200 pairs (Gjershaug et al. 1994) and the species has been classified as «Rare» in the national Redlist (Direktoratet for naturforvaltning 1999). In Norway, Water Rails are easiest to locate during the winter months along the western coast (north to Trøndelag), although the species is regarded as a typical migrant that leaves the country in October and returns in April (Haftorn 1971, Folkestad 1991).

In Aust-Agder county, South Norway, the Water Rail is primarily found in a narrow belt along the coastline. Until now the species has here been regarded as rare and with an unstable occurrence (Pfaff \& Bengtson 1995), but it has presumably been overlooked due to its secretive habits, and has therefore gained an uncertain status in the regional red list (Pfaff \& Bengtson 1995). Here we present the results of Water Rail censuses in Aust-Agder carried out through seven consecutive winters. We test for effects of climate on the species' occurrence by relating our rail counts to air temperatures in the study area, and summarize some notes on densities and the birds' response to play-back calls.

\section{MATERIAL AND METHODS}

We limited the census to the coastline because Water Rails had never been observed more than 10-20 km inland in Aust-Agder before our project started. The study area mainly consists of the municipalities of Arendal, Grimstad and Lillesand, but a few more sporadic observations are also included from localities in Birkenes, Tvedestrand and Risør (Appendix 1, Fig. 1). All localities are situated less than $10 \mathrm{~km}$ from the outer coastline, except the lake Berse (15-20 $\mathrm{km}$ inland). The surveyed sites were shores of freshwater lakes, freshwater swamps or marshes adjacent to brackish or salt water. Because reedbeds constitute a preferred habitat for Water Rails (Cramp \& Simmons 1980, Jenkins \& Ormerod 2002), we have almost exclusively monitored wetlands with dense populations of reed (Phragmites).
Data were collected between December 1998 and January 2005. To efficiently locate the rails, we used play-back calls from Wahlström (1995) to provoke a response if the birds were present in an area. Play-back was carried out from the edge of reed-beds between dawn and dusk (08:30-16:30); i.e. never in total darkness. The total play-back time always lasted between approximately two and four minutes in two to six bouts at each site. The CD-recording consisted of three main types of calls (see Cramp \& Simmons 1980 for detailed descriptions): 1) tick-and-scream 2) courtship song and 3) announcement call, hereafter referred to as «pig squealing». All these were played at least once at all sites at each visit.

The Water Rails responded in somewhat different ways to the play-back calls. Some birds responded by calling almost immediately after the tape started, while others had to be provoked by play-back several times or did not respond until more than 10 minutes after the last play-back bout was finished. Yet other birds uttered no calls at all, although they were clearly attracted by the broadcast vocalizations and approached the observers by running, or more rarely by flying towards the cassette player and landing in the nearby dense vegetation. When birds responded by calling, they were more likely to use the «pig squealing» call than other call types (40 of 42 times when exact type of response call was recorded) (Binomial test: $P<0.0001$ ), but sometimes the birds continued using other screams or low-volume chattering as well. Of a total of 63 individuals in which the response behaviour was noted, five $(8 \%)$ were only seen and not heard at all. When birds were recorded as remaining silent, this could be because observers spent too short a time at a site. However, in two cases we spent more than 20 minutes observing two single rails that did not call, despite play-back being repeated several times. These observations indicate a rather large individual variation in response behaviour.

We have here included all observations of wintering Water Rails that are known to us from the 


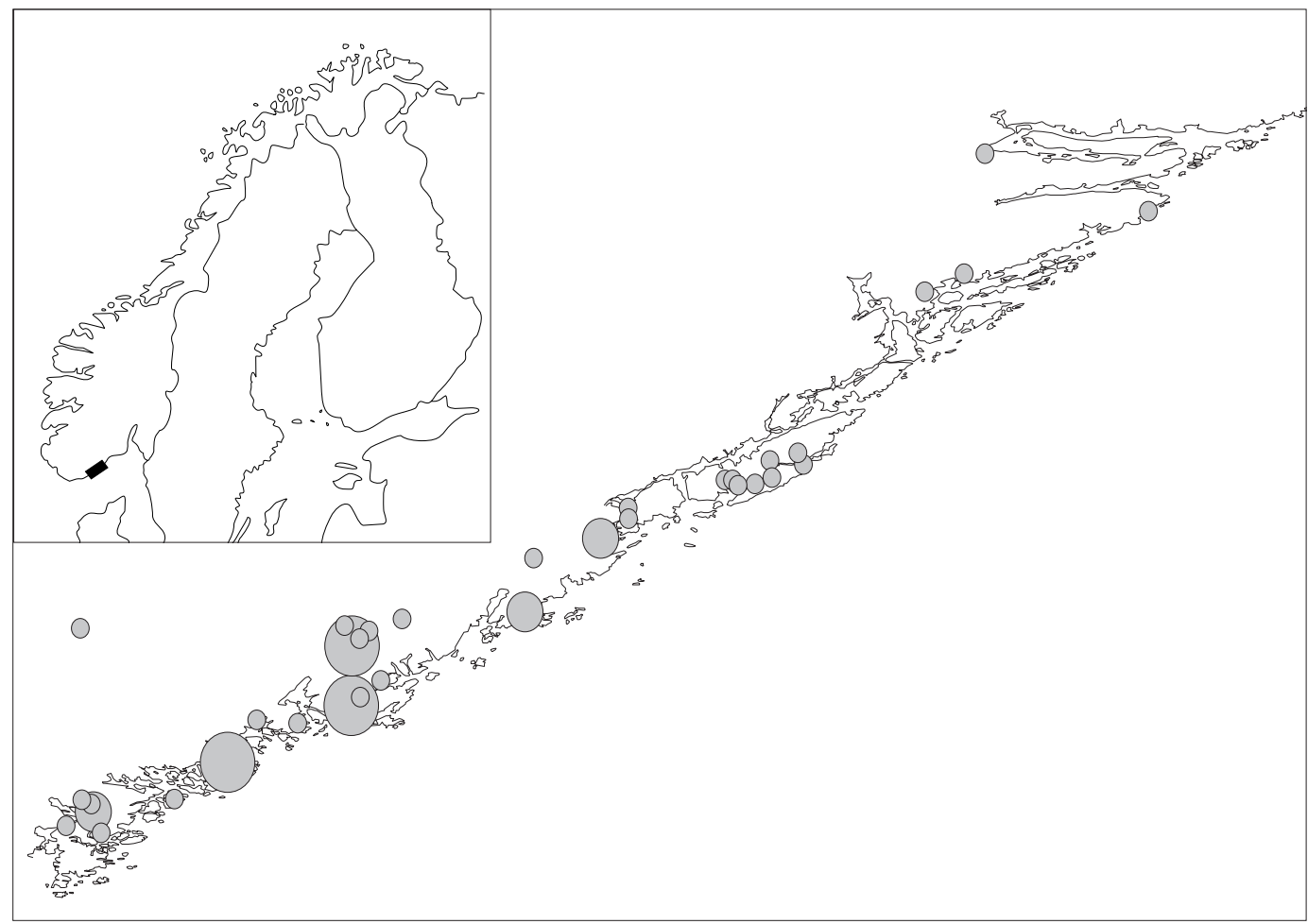

Figure 1. Map showing the study area along the coastline of Aust-Agder; localities where Water Rails have been found are plotted in relation to the maximum numbers of birds observed per season. Small circles indicate 1-5 birds, medium circles 6-10 birds and large circles 11-20 birds. The black rectangle on the smaller map shows the location of the study area in Fennoscandia.

Figur 1. Kart over studieområdet langs kysten av Aust-Agder, med inntegnet lokaliteter der det ble observert vannrikser. Lokalitetene har blitt plottet i forhold til det høyeste antall fugler som ble registrert på lokalitetene. Små sirkler indikerer 1-5 individer, mellomstore sirkler 6-10 individer og store sirkler 11-20 individer. Det svarte rektangelet på det lille kartet viser studieområdets beliggenhet $i$ Fennoscandia.

study area. This also includes some that were provided by other observers. However, in order to get data that could tell us something about the variation in numbers between seasons, we tried to standardize the census with regard to time and weather conditions. It was not possible for the observers to cover all the sites on the same day in any of the years. As far as possible, counts were carried out between 17 and 23 December, but exceptions had to be made in most years (Table 1). Although temperatures varied extensively between seasons, weather conditions were similar during each census (clear sky or thin cloud cover without precipitation and wind). In order to check for climatic effects on the number of Water Rails, we relate yearly numbers to temperature data from the weather station at Torungen lighthouse, Arendal, provided by the Norwegian Meteorological Institute (http://eklima.met.no). We calculated average air temperatures from the months October, November and December as an estimate of climatic conditions each autumn. In addition, it is possible that the population size one autumn would be negatively influenced by harsh climatic conditions the previous winter. We explored this possibility by relating Water Rail numbers with the mean air temperatures from December through March in the preceding winter. 
Table 1. Dates when winter counts of Water Rails were carried out in Aust-Agder between 1998 and 2004. Days in brackets denote observation days not included in the standard counts.

Tabell 1. Datoer da vintertellingene av vannrikser ble gjennomf $\phi$ rt i Aust-Agder mellom 1998 og 2004. Dager i parentes angir observasjonsdager som ikke inngår $i$ standardtellingene.

\section{Winter}

1998-1999

$1999-2000$

2000-2001

2001-2002

2002-2003

2003-2004

2004-2005

\section{Dates of survey}

18,19 and 20/12 (29 and 30/12,3/1, one site each on the three last dates)

$18,19,20$ and 21/12 (13 and 28/12, 1,5 and 14/1)

$17,19,21$ and $22 / 12$

21 and $23 / 12$

$15,19,20,21$ and $22 / 12$

$19,20,22$ and $28 / 12$

18,19 and 20/12, $15 / 1(24,30$ and 31/12, 6 and 23/1)
Densities of birds are calculated for some selected localities with especially high counts. These estimates are based on the area of the reed-bed only. As we did not record any of the responding birds sitting outside the reed-beds, this method should give a representative estimate of maximum density.

\section{RESULTS}

We found wintering Water Rails in a total of 38 wetlands. An overview of these sites and the number of birds located each year is presented in Appendix 1, while the locations are plotted in Figure 1. The total number of individual birds found in the survey each year varied between 4 and 103 (Appendix 1). Most pronounced was the difference in numbers at Inntjorekilen and Fossdalskilen, Grimstad. Here counts varied from 1 to 20 birds and from 0 to 15 birds respectively (Appendix 1). At the localities where we found the highest number of birds, densities (number of birds/daa reed-bed area) in the best seasons were found to be at least 0.37 at Fossdalskilen (40 daa), 0.43 in Inntjorekilen (47 daa) and 0.34 in Øreslandskilen (26.5 daa).

Differing climatic conditions form a likely explanation for the annual variation in rail numbers. For example, in the year with fewest birds (2002) there was little open water at most of the sites, whereas in the year with most birds (2000) almost no water surface was frozen in the study period throughout the whole study area. We found a positive correlation between the Water Rail counts and autumn temperatures, both when we only included sites that were visited in all years $(n=21)$ (linear regression: $r^{2}=0.56, P=0.053$, $n=7$; Fig. 2), and when all observations were included (linear regression: $r^{2}=0.58, P=0.048, n$ $=7$ ). Rail numbers did not depend on temperature conditions the preceding winter (linear regression: $\left.r^{2}=0.09, P=0.52, n=7\right)$.

Data available from one of the seasons suggest that the number of Water Rails declined during the winter in our study area, as the number of 


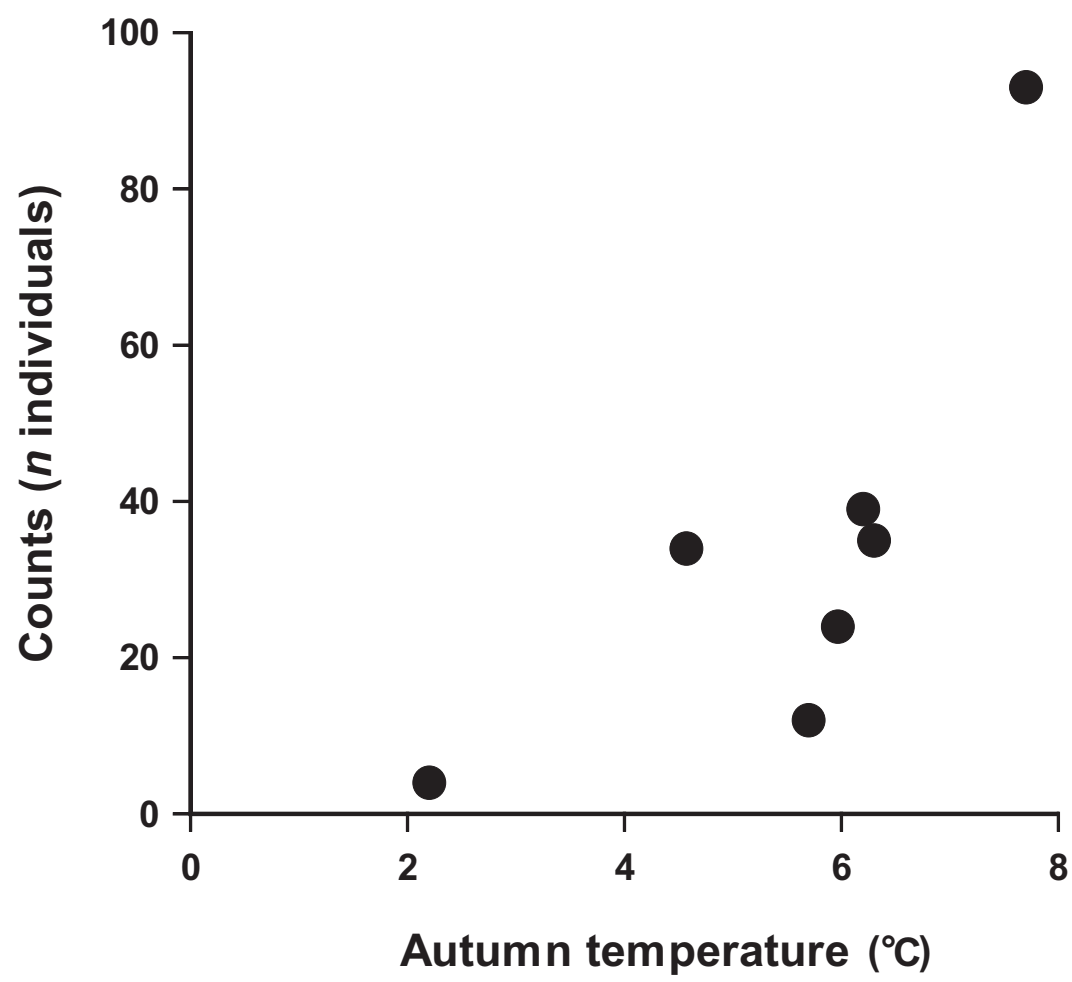

Figure 2. The total number of Water Rails observed per autumn in Aust-Agder was positively correlated with autumn temperature (average temperature in the months October, November and December) the same year $\left(r^{2}\right.$ $=0.56, P=0.053, n=7)$. Only the sums of Rail numbers from localities that were visited all years are included. Temperature data are from the weather station Torungen lighthouse, Arendal.

Figur 2. Antall vannrikser observert midtvinters $i$ Aust-Agder var positivt korrelert med høsttemperaturen (gjennomsnittlig temperatur i månedene oktober, november og desember) samme år $\left(r^{2}=0.56, P=0.053, n=\right.$ 7). Kun summene av vannriksetellinger fra lokaliteter som ble bes $\phi$ kt hvert år er inkludert. Temperaturdata er hentet fra varstasjonen ved Torungen fyr, Arendal.

birds responding to play-back calls in early spring (4 April 1999; 10 birds recorded) was significantly lower than the early winter counts (late December and 1 January; 22 birds recorded) (Wilcoxon matched-pairs test: $Z=-2.37, P<$ $0.02, n=12$ sites).

\section{DISCUSSION}

This study demonstrates that Water Rails are regular winter visitors along the coast of AustAgder. As far as we know, this is the first Norwegian study to quantify the yearly variation in numbers of wintering Water Rails. Consequently, the study adds some important information to our knowledge about the species' winter occurrence in Norway.

Despite the few previous records in Aust-Agder, we found the occurrence of Water Rails to be predictable at sites which had relatively large and dense reed-beds. Our observations through seven winters clearly showed that the presence of many rails was not only an occasional occurrence due to an invasion-like phenomenon. Instead we can conclude that the south-eastern part of Norway constitutes a regular wintering area for Water Rails. From our observations, it seems probable that at least 100-200 Water Rails could be found 
during winter in Aust-Agder in the best years. This must be regarded as a minimum estimate, because 1) some important wintering sites for the species could have been overlooked since we have probably not checked all suitable localities in the county, and 2) it is not likely that all birds were detected at each site because of methodological draw-backs (see below). Further, since only reed-beds were checked, we do not know whether the species also frequents other kinds of habitat. Dense reed-beds are typically found only along the coast in this part of Norway, and this could perhaps explain why the rails seem to be very rare inland here. However, along the western coast of Norway, Water Rails are commonly found in various types of dense aquatic vegetation, at least in Hordaland county (TL pers. obs., F. Falkenberg, pers. comm.). Further studies of the species' habitat choice in Norway would therefore be useful in order to better understand its distribution. Density estimates from different habitats would also be valuable to gain a better overview of population size.

The numbers of wintering Water Rails fluctuated considerably between years in Aust-Agder. Climatic conditions are likely to be the main cause of this phenomenon, because of the positive correlation between numbers and average autumn temperature. The exact reason for lower numbers in colder years is not known, but several possibilities exist. First, colder autumns may lead to emigration from wintering sites. Second, periods with cold weather may increase mortality early in the season. Finally, it is possible that fewer birds make wintering attempts in South Norway during cold autumns, and move to milder areas instead. Little is known about the origin of birds wintering in Norway, as only four foreign and five natively ringed birds are currently known to have been recovered in this country (A. Folvik pers. comm.). These include one bird from Finland, two from Latvia (all recovered in November), and one from Germany (recovered in December). The German bird was actually found in Lillesand, Aust-Agder. Two of the five Norwegian birds were recovered in winter (January), but no Nor- wegian ringed birds have been recovered abroad so far (Bakken et al. 2003).

Although sparse, our data indicate that the numbers of wintering Water Rails declined towards early spring. One likely explanation is that birds die as the winter proceeds, or migrate away from the region due to severe climatic conditions (Jenkins et al. 1995). It is also possible that the birds come from other regions of Norway and Europe, and return to their breeding areas. Yet another possibility is that the response to broadcast vocalizations changes and makes the birds less willing to reply at the start of the breeding season. The latter possibility seems less likely, however, as other studies have shown that the species frequently responds to play-back calls also when breeding (Bengtson \& Steel 1994, Jenkins \& Ormerod 2002).

The present study has clearly demonstrated the efficiency of play-back use in surveys of Water Rails. However, for unknown reasons, the birds varied to a great extent in response behaviour. As a consequence, it is reasonable to assume that using the play-back method does not reveal the presence of all rails in an area. Accordingly, a study by Jenkins et al. (1995) indicated a much higher population density of rails when birds were trapped, than what has normally been found by indirect observations. In accordance with studies in the breeding period (Jenkins \& Ormerod 2002), we conclude that broadcast vocalizations are an effective means of mapping the occurrence of Water Rails also during winter. Finally, because of the individual variation in response to play-back, observers should wait at least ten minutes before leaving a locality if no rails reveal their presence immediately.

\section{ACKNOWLEDGEMENTS}

We thank Roald Bengtson, Frode Falkenberg, Asbjørn Folvik, Arne Heggland, Leif Salve Håkedal, Tom Anders Johannessen, Rune Skåland and Kjell Woxmyhr for different kinds of 
helpful information about Water Rails. In the field, we enjoyed the pleasant company and assistance of Victoria Fuhr, Leif Gunleifsen, Jan E. Gunnersen, Knut Høgevold, Kjell A. Johansson, Arvid Johnsen, Jannicke Kjøstvedt, Geir K. Knudsen, Inge Selås, Vidar Selås and Christian Steel. Thanks also to Christian Steel for making the map of Water Rail localities.

\section{SAMMENDRAG}

\section{Overvintrende vannrikser Rallus aquaticus i Aust-Agder fylke}

Lite er kjent om opptredenen til vannriksa Rallus aquaticus i Norge, særlig om vinteren. På bakgrunn av tellinger utført rundt juletider unders $\varnothing \mathrm{kte}$ vi artens vinteropptreden langs kysten av AustAgder gjennom sju påfølgende sesonger. Studiet ble utført ved å spille av opptak av vannrikselyd for således å framprovosere en respons hvis arten var til stede. Unders $\varnothing$ kelsene viser at vannriksa ikke er en sjelden art om vinteren i denne delen av Norge, med opp til 103 fugler registrert én enkelt sesong (desember 2000). Antall individer varierte imidlertid betydelig mellom år. En positiv korrelasjon mellom antall rikser og gjennomsnittlig lufttemperatur i månedene oktober-desember tyder på at klimatiske forhold $\mathrm{i}$ betydelig grad påvirker vannriksas opptreden. Data fra ett av årene viste at antall fugler som svarte på avspilt lyd avtok til begynnelsen av april, men hvorvidt dette skyldes dødelighet, emigrasjon eller andre faktorer er ikke kjent. Generelt responderte riksene sterkt på lydavspilling, oftest ved å svare med det såkalte «grisehylet». Likevel lot det til å være en ganske stor individuell variasjon i respons, da noen fugler ble hørt flere ganger, mens andre ikke svarte $\mathrm{i}$ det hele tatt men bare ble sett smygende gjennom vegetasjonen rundt lydkilden. Våre observasjoner tyder på at minst 100-200 vannrikser fors $\varnothing$ ker å overvintre i AustAgder i gode år. Siden undersøkelsen neppe dekket alle lokaliteter med overvintrende vannrikser i fylket, og på grunn av at ikke alle rikser svarer på lydavspilling, må dette estimatet ansees som et minimum.

\section{REFERENCES}

Bakken, V., Runde, O. \& Tjørve, E. 2003. Norsk RingmerkingsAtlas. Vol. 1. Stavanger Museum, Stavanger. (In Norwegian, with English summary).

Bengtson, R. \& Steel, C. 1994. Vannrikse. S. 154 i: Gjershaug, J. O., Thingstad, P. G., Eldøy, S. \& Byrkjeland, S. (red.) Norsk fugleatlas. Norsk Ornitologisk Forening, Klæbu.

Cramp, S. \& Simmons, K. E. L. (eds.) 1980. The Birds of the Western Palearctic, Vol II. Oxford University Press, Oxford.

Direktoratet for naturforvaltning 1999. Nasjonal rødliste for truete arter 1998. Norwegian Red List 1998. DN-rapport 1999-3.

Flegg, J. J. M. \& Glue, D. E. 1973. A Water Rail Study. - Bird Study 20: 69-79.

Folkestad, A. O. 1991. Traner og rikser. S. 65-82 i Hogstad, O \& Semb-Johansson, A. (red.). Norges dyr. J. W. Cappelens forlag.

Gjershaug, J.O., Thingstad, P.G., Eldøy, S. \& Byrkjeland, S. (red.) 1994. Norsk fugleatlas. Norsk Ornitologisk Forening, Klæbu.

Haftorn, S. 1971. Norges fugler. Universitetsforlaget, Oslo.

Hagemeijer, W. J. M. \& Blair, M. J. (eds.) 1997. The EBCC Atlas of European Breeding Birds. Poyser.

Jenkins, R.K.B., Buckton, S. T. \& Ormerod, S. J. 1995. Local movements and population density of Water Rails Rallus aquaticus in a small inland reedbed. - Bird Study 42: 82-87.

Jenkins, R.K.B. \& Ormerod, S.J. 2002. Habitat preferences of breeding Water Rail Rallus aquaticus. - Bird Study 49: 2-10.

Kjøstvedt, J. H. \& Lislevand, T. 2001. Hekkefunn av vannrikse Rallus aquaticus i Aust-Agder. - Larus marinus 30: 109-115.

Myklebust, M. 1996. Truete fuglearter i Norge. Norsk Ornitologisk Forening, Rapport nr. 5 - 1996, Klæbu.

Pfaff, A. \& Bengtson, R. 1995. Truete virveldyr $i$ Aust-Agder. Biologisk Institutt, Universitetet i Oslo.

Tucker, G. M. \& Heath, M. 1994. Birds in Europe. Their conservation status. BirdLife International, Cambridge, U.K. (BirdLife Conservation Series no. 3).

Wahlström, S. 1995. Fuglesang. Lydene til 197 nordiske arter. CD med lydspor. Norges Naturvernforbund. 
Appendix 1. Localities in Aust-Agder where wintering Water Rails were found during the winters 1998/99 -2004/05, and the number of birds found each year (no numbers are given in years when sites were not visited).

Lokaliteter hvor det ble funnet overvintrende vannrikser i Aust-Agder vintrene 1998/99 - 2004/05, og antall fugler som ble funnet hvert år (ingen antall er oppgitt for år uten bes $\phi k$ ).

\begin{tabular}{|c|c|c|c|c|c|c|c|c|}
\hline \multirow[b]{2}{*}{ Locality } & \multirow[b]{2}{*}{ Municipality } & \multicolumn{7}{|c|}{ Year } \\
\hline & & 1998 & 1999 & 2000 & 2001 & 2002 & 2003 & 2004 \\
\hline Alve & Arendal & 1 & 0 & 3 & 0 & 0 & 0 & - \\
\hline Botnetjenna & Arendal & 2 & 2 & 3 & 1 & 0 & 0 & 2 \\
\hline Flangeborg & Arendal & 0 & 1 & 2 & 0 & 0 & 0 & 1 \\
\hline Færvikkilen & Arendal & - & 0 & 2 & - & 0 & 0 & 1 \\
\hline Færvikkrysset & Arendal & 0 & 3 & 4 & 2 & 0 & 0 & 0 \\
\hline Gjervoldsøy & Arendal & 1 & 0 & 0 & 0 & 0 & - & 2 \\
\hline Lille Gjerstadvann & Arendal & 1 & 1 & - & - & 0 & 0 & 0 \\
\hline Skottjenn & Arendal & - & 0 & 1 & 1 & 0 & 0 & 1 \\
\hline Sandumkilen & Arendal & 2 & 1 & 1 & 0 & 0 & 0 & 0 \\
\hline Saulekilen & Arendal & 4 & 1 & 6 & 6 & 0 & 0 & 2 \\
\hline Utnes & Arendal & - & - & - & - & - & - & 1 \\
\hline Vippa bru & Arendal & 1 & 0 & 0 & - & - & - & - \\
\hline Berse & Birkenes & 0 & 1 & 0 & - & - & - & 1 \\
\hline Fossdalskilen & Grimstad & 4 & 9 & 15 & 0 & 1 & 2 & 6 \\
\hline Engekilen & Grimstad & 0 & 1 & 2 & 0 & 0 & 1 & 2 \\
\hline Hessnes & Grimstad & 3 & 2 & 7 & 3 & 1 & 0 & 2 \\
\hline Inntjoretjenna & Grimstad & - & - & 2 & - & - & - & 0 \\
\hline Inntjorekilen & Grimstad & 1 & 1 & 20 & 2 & 0 & 2 & 3 \\
\hline Landvikvann & Grimstad & 1 & 1 & 2 & 1 & 0 & 0 & 2 \\
\hline Reddalsvann, nord & Grimstad & 1 & 0 & 1 & 1 & 0 & 0 & 0 \\
\hline Reddalsvann, øst & Grimstad & 1 & 0 & 2 & 0 & 0 & 1 & 0 \\
\hline Temse & Grimstad & 1 & 2 & 2 & 2 & 0 & 0 & 2 \\
\hline Vågsholt & Grimstad & 0 & - & 2 & 0 & 0 & - & 0 \\
\hline Eidjord & Lillesand & 0 & 0 & 2 & 0 & 0 & 0 & 0 \\
\hline Frillestadkilen & Lillesand & 0 & 0 & 0 & 0 & 0 & 1 & 0 \\
\hline Kallandstjenna & Lillesand & 2 & 0 & 1 & 1 & 0 & 0 & 0 \\
\hline Kjøstvedtkilen & Lillesand & 0 & 0 & 1 & 0 & 0 & 1 & 0 \\
\hline Klingsund & Lillesand & - & 1 & 0 & 1 & 0 & 0 & 0 \\
\hline Kvanes & Lillesand & 1 & 3 & 2 & 0 & 0 & 1 & 2 \\
\hline Østerøykilen & Lillesand & 7 & 6 & 11 & 1 & 0 & 1 & 1 \\
\hline Skallefjorden & Lillesand & - & - & 0 & 0 & - & - & 1 \\
\hline Tingsaker & Lillesand & 1 & 2 & 1 & 1 & 0 & 0 & 1 \\
\hline Øreslandskilen & Lillesand & 3 & 4 & 8 & 3 & 2 & 2 & 9 \\
\hline Åkerøya & Lillesand & - & 2 & - & - & - & - & - \\
\hline Krabbesund & Risør & - & 2 & - & - & - & - & 1 \\
\hline Rød, Sørfjorden & Risør & - & 1 & - & - & - & - & - \\
\hline Frydendalstjenna & Tvedestrand & - & 1 & - & - & - & - & - \\
\hline Krokvågkilen & Tvedestrand & - & 3 & - & - & - & - & - \\
\hline TOTAL & & 38 & 51 & 103 & 26 & 4 & 12 & 43 \\
\hline
\end{tabular}

